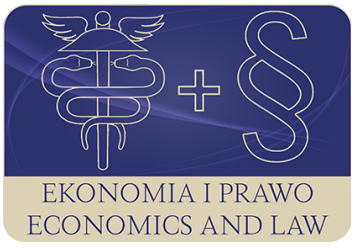

EKONOMIA I PRAWO. ECONOMICS AND LAW

Volume 20, Issue 4, December 2021

p-ISSN 1898-2255, e-ISSN 2392-1625

www.economicsandlaw.pl

ORIGINAL ARTICLE

received 15.05.2021; revised 01.12.2021; accepted 31.12.2021

Citation: Godłów-Legiędź, J. (2021). On the academic freedom in the times of crisis of liberal democracy. Ekonomia i Prawo. Economics and Law, 20(4), 731-743. https://doi.org/10.12775/EiP.2021.043.

\title{
On the academic freedom in the times of crisis of liberal democracy
}

\author{
JANINA GODEÓW-LEGIĘDŹ \\ University of Lodz, Faculty of Economics and Sociology, Department of Institutional Economics \\ and Microeconomics, ul. Rewolucji 1905 r. 41/43, 90-214 Łódź, Poland \\ $\square$ janina.legiedz@uni.lodz.pl \\ (D) orcid.org/0000-0001-6831-8902
}

\begin{abstract}
Motivation: The crisis of liberal democracy reveals a new dimension to the dispute over the role of the university. Declining trust in elites and the growing uncertainty during the pandemic challenge the belief that the key aim of the university reform should be to subject it to the global mechanism of competition as well as to introduce modern management principles. In the American society, there is a growing belief that the higher education system in the United States is heading in the wrong direction and that universities are politically biased. Despite this, the American system inspires higher education all over the world, including Poland. Even during the pandemic, the attention of the academic community in Poland is focused on the lists of journals constituting the basis for the evaluation of universities and academics.

Aim: The aim of the article is to demonstrate the threats posed by a higher education system governed by the dominant economic and political forces. The author evaluates the economic forces behind the parameterisation and ranking system, challenging the rationality of the Polish higher education reforms. The source of the arguments for academic freedom is the political economy that places economic goals in the perspective of longterm universal goals and examines the complex relationships between the economic, political and moral aspects.

Results: Academic freedom is not a privilege of the academic world, but one of the foundations of the successful development of a democratic society because science and education cannot be subject to existing patterns of thinking and current economic and political forces. But modern universities are driven to act like firms in competitive market places and they are following trends set by short-term economic and politic interests. Political economy is an effective tool for analysing functioning of higher education operating
\end{abstract}


in quasi-market conditions, imposed by the dominant market players and the state. Understanding the forces underlying the reform of universities requires an analysis of the processes of interpenetration of economic and political processes, which means that the paradigm of political economy is gaining importance. In view of the requirements imposed on universities, dictated by short-term interests, the most important thing is the awareness that the necessity of state financing means that no solution will guarantee autonomy, if there is no responsibility of the academic community and self-discipline of its members.

Keywords: academic freedom; democracy; political economy; neoliberalism JEL: All; A20; I25

The regime of equality and liberty, of rights of man, is the regime of reason. The free University exists only in liberal democracy, and liberal democracies exists only where are free universities.

Bloom (2012, p. 259)

\section{Introduction}

The participants of the Science and Freedom congress, held in Hamburg in July 1953, undertook an interdisciplinary discussion on the methodological and institutional premises of the freedom of science and education. On the one hand, the context of this discussion was the terrible experience of the Nazi and Stalinist totalitarianism, and on the other, the growing suspicions about universities as "seed-beds of intellectual insubordination" (Polanyi, 1953, p. 322). In 2021, the context of the considerations on academic freedom encompasses the crisis of liberal democracy and the pandemic as well as the systems of parametric tests and rankings, in which modern universities function. The crisis of liberal democracy, revealing the lack of trust in the global and national dimensions, justifies the need for a similar gesture from intellectual circles. There is a need to analyse the causes of the crisis of liberal values and to define the role of universities in this process. The majority of the American society believes that the schooling system in the United States is heading in the wrong direction and that universities are politically biased (Parker, 2019). This must be alarming in the context of the growing political divides and the fact that the incentive system of the best American universities is an inspiration for higher education in the world, also in Poland. The fact that this concern does not lead to initiatives similar to the post-war congress in Hamburg is probably a consequence of the institutional state of higher education. In Poland, even in times of the pandemic, the issue of the contents of the lists of journals determining the promotions and bonuses of academics comes to the fore.

The aim of the article is to demonstrate the threats posed by the higher education system based on competition governed by bureaucracy. Condemning the subordination of universities to the dominant economic forces, we indicate the dangers of transferring corporate management methods to universities 
and replacing traditional academic values with the enigmatic idea of excellence. On the one hand, we notice the manifestations of academic capitalism, and on the other, we present arguments supporting the need to implement the idea of liberal education. The staple that binds the utilisation of these concepts is the idea of academic freedom and the conviction that this freedom is an important condition for maintaining peaceful development, particularly in the period of dynamic changes, which we are experiencing in the 21st century. Global uncertainty and the fear that a changing university is being subordinated to short-term economic and political goals make the topic of academic freedom especially significant. The point is not to defend the interests of academic staff but to analyse the forces, which the modern university is subject to, as well as to defend the university as an institution, at which the dominant interests and ways of thinking are not accepted indiscriminately, and perhaps even, as Derrida (2002, p. 202) radically points out, in which it is possible to question almost everything. This explains why, when considering the problem of academic freedom, one should adopt the perspective of political economy. Political economy does not limit economic analysis to the allocation of limited resources among unlimited goals, but places economic goals in the perspective of long-term universal goals and examines the complex relationships between the economic, political, and moral aspects. This perspective calls for the question of whether a reform, which focuses on parameterisation, market response, competitiveness, and islands of excellence, would be compatible with the demands of academic freedom, and whether it would enable universities and higher education to contribute to resolving the growing contradictions of the modern world.

In the article, the author uses desk research and personal experiences. This research method consists in combining the logical analysis of the existing knowledge and views of other researchers with a specific diagnosis of the social situation on the basis of many years of staying and functioning in a given, changing social, economic and political environment. The article is based on literature studies and many years of experience of working at a university in the times of central planning and transition from plan to market.

\section{Academic freedom matters}

Academic freedom is a prerequisite for the existence of a society that reconciles the freedom of an individual with the common good. It is an important institution, the roles of which include the defence against various forms of totalitarianism. This was understood by the participants of the post-war congress in Hamburg. The discussion centred around the question of how a community, whose survival and progress depend on its autonomy, can on the one hand withstand the pressure of political fanatics and doctrinaires, and on the other, avoid becoming financially dependent on government bodies (Shils, 1954, p. 152). This question has gained importance again but needs to be completed. How to defend universities from superficial market pragmatism and from following 
the direction determined by politics arising from the intertwining of the state power and the market? When the global economic and political uncertainty, significant inequalities, terrorism as well as the pandemic cause increasing concern about the preservation of liberal and humanistic values, there is an urgent need to return to the "ferment of economic thinking" that emerged in the 1930s and the 1940s in response to the global crisis and war (McCants, 2016, p. 26).

Polanyi was a participant of the Hamburg Congress and took part in the discussions of the 1930s and the 1940s. He saw the problem of the intellectuals' freedom both from the perspective of the tyranny of the Stalinist and fascist systems as well as the dilemmas of the utilitarian economy. His argument for the freedom of scientific research was born out of a discussion with Bukharin in 1935. Polanyi argued that science should be centrally planned in order to serve the common good. He defended the distinction between pure and applied science because, in negating this distinction, he saw the underlying assumption of totalitarianism. Defending the idea of pure science as the pursuit of truth for its own sake, he regarded academic freedom as a fundamental value of a free society, the aim of which is to provide conditions allowing people to recognise moral and intellectual values. Polanyi rejected the utilitarian belief that the pursuit of understanding nature must be subordinated to economic goals and the realisation of prosperity. He treated scepticism and instrumental-utilitarian interpretations of science and law as sources of tension in the liberal concept of freedom, carrying totalitarian threats. However, he also rejected Kant's concept of inner freedom as the ability to recognise moral rightness and acting in accordance to unconditional moral duty. He was afraid that this understanding of freedom could easily turn into totalitarian ideologies. This can happen when the state, nation or party is given the status of an exponent of the public good and a source of moral obligations of an individual (Hartl, 2012, p. 310).

On the one hand, the positions of universities as well as the scope of their independence and self-governance are consequences of beliefs regarding their position in the process of creating knowledge and education. On the other hand, they result from state policy and profound changes taking place in national economies under the influence of globalisation. The historically shaped image of the role of the university as a unique community, which due to the function of critical thinking enjoys special protection of independence, is opposed by the notion that similarly to other institutions functioning in the market economy, the university should be subject to the rules of economic rationality and cotemporary management rules. This antinomy is metaphorically expressed by juxtaposing the university as Sisyphus and the reformist forces wishing to adapt the university to the modern world as Midas (Stawek, 2011, p. 25). From the viewpoint of the university as Sisyphus, the independence of the university is a consequence of treating its activities as public good, the realisation of which is guaranteed neither by the dominant market forces nor by the state entangled in dependence on market forces and democracy. The university favours the public good when there are formal and informal conditions for prac- 
ticing critical thinking. Improving thinking and fostering the greatest possible variety of ideas are the basic functions of the university, which meet contemporary and not yet known challenges. Improving thinking helps to make better decisions and can bring the world closer to a state with fewer unintended effects of human actions (Bowen et al., 2014, p. 200). It takes place in research and teaching processes, and concerns both academic staff and students. Education can be considered a special transmission belt from those who create knowledge to the whole of society. This is why a university serving the public good is one, at which there is a balance between the research and teaching functions.

\section{The idea of perfection}

On the one hand, the academic freedom is threatened by bureaucratic forms of management, in which the prestige distribution system based on global rankings and impact indicators is central, and on the other hand, by the policy of subordinating the education process to the current needs of the market and the ideology of economic growth. Both are linked by the enigmatic idea of perfection.

In discussions and official documents, excellence is so often called a tangible target, even though modern cognitive psychology makes people aware of cognitive distortions and the pitfalls of human thinking. Performing the functions of a scientist and academic lecturer requires special diligence, faithfulness to the principles of scientific practice and ethics, but also criticism towards one's own research results and beliefs. As argued by Kahneman (2012, pp. 294, 348), scientists and experts are also subject to cognitive biases, overconfidence and over-optimism ${ }^{1}$. This may mean that the rhetoric of excellence is contrary to the scientific methodology, the inherent feature of which is a critical attitude towards the applied research methods and research results as well as awareness of the incompleteness of the acquired knowledge. The rhetoric of excellence and the related system of motivation are intended to raise the position of universities in global rankings; however, they remain in contradiction with the nature of creative work, which requires internal commitment and criticism towards the existing solutions and habits of thinking ${ }^{2}$.

1 The occurrence of cognitive heuristics in scientific research is confirmed by contemporary sociology, namely the situation analysis by Konecki (2020, p. 188). The author writes about phenomena such as the sociologisation of attention, ignoring theory in sociological research, frame trap, the problem of selective and active inattention, and institutional attention management.

2 Motivation theorists see the need to replace the Motivation 2.0 system based on subordination with a system that relies on autonomy and internal commitment. Motivation 3.0 assumes that "people have a third drive — to learn, create and improve the world" (Pink, 2012, p. 214). The effects of similar initiatives of excellence in the German education system were already described in Poland 10 years ago (Kehm, 2011, p. 229). 
The growth of regulations and bureaucracy in higher education is a way of exercising power, the essence of which is the threat of violence. It is a structural type of violence (Graeber, 2016, p. 79), which restricts freedom in a sophisticated way. The freedom of science is threatened when the necessary trust in the scientific community, built on methods of selecting scientific staff and intersubjective testing of the generated knowledge, refined over centuries, are replaced by increasingly intensive attempts to replace bureaucratic science management mechanisms (Morawski, 2019, p. 178). In a country with an experience of a communist system, we feel more clearly than in the West that one of the greatest paradoxes of the modern world is that the growth of bureaucracy and legal instrumentalism occurred after the overthrow of the central planning system, at the time of the triumph of freedom and the market (Graeber, 2016, p. 178). Concurrently, we lack awareness of the risks arising from building a society on based on ubiquitous mechanisms of competition. In a country, where the memory of a system that guarantees relative economic security is still quite fresh, it is worth recalling the thesis that totalitarian tendencies are inversely proportional to the probability of finding a satisfactory place in society. Given that the number of top positions is limited and only a few win, failures can be psychologically devastating (Greenfeld, 2016). And yet, regardless of which political party the minister of higher education was associated with, the undisputed aim of the reform was to improve the position of Polish universities in international rankings. Law and Justice is a party that gained power under the slogan of replacing liberal Poland with solidarity Poland. But it was under the rule of this party, that the concept of financially privileging 10 universities called "Initiatives of Excellence" was introduced. The concept of top-down creation and consolidation of inequalities was adopted in a situation where one of the main problems of the modern world is growing inequalities. The prevailing opinion is that inequalities are the result of the market. Meanwhile, the "Initiatives of Excellence" is an example of a policy that empowers the stronger and works towards inequality ${ }^{3}$. In the context of social sciences, this question must be related to the crisis of liberal democracy.

\section{Academic capitalism, the market and neoliberalism}

The higher education reforms implemented in Poland over the last 10 years have been directly related to Poland's membership in the European Union; however, one ought to consider the changes that took place at public universities in the United States, Great Britain, Australia and Canada during the period between 1970 and 1995 as their prototype. The transformation of Anglo-Saxon higher education is linked to the neoliberal transformation policies of Ronald Reagan and Margaret Thatcher. The growing awareness of the role of knowledge as a production factor was an important aspect within this transforma-

${ }^{3}$ The effects of similar initiatives of excellence in the German education system were already described in Poland 10 years ago (Kehm, 2011, p. 229). 
tion. It contributed to the growing interest in intellectual property rights and to the perception of university activity as a new space for capital accumulation. The development of the academic publishing industry has become a significant component of the new entrepreneurship sector based on knowledge production. In the period between 1990 and 2000, the average journal prices in natural and technical sciences, medical sciences and humanities as well as social sciences increased by 123, 111 and $127 \%$, respectively, while retail prices in this period in Great Britain increased by an average of 38\%. This discrepancy between the dynamics of scientific journal prices and the price index of goods in general continued in the period between 2001 and 2006 (Pirie, 2009, p. 37; White \& Creasen, 2007, pp. 13-17). According to an analysis conducted by Cambridge Economic Policy Associates in 2008, the profit margins of leading college publishers were $25 \%$, while those of commercial publishers were $35 \%$. The high profits of commercial publishers are especially outrageous because they are not invested in science or education. Instead, they end up in the pockets of shareholders (van Noorden, 2013, p. 427). These are manifestations of academic capitalism, which developed as a result of introducing quasi-market activities into education. Managing higher education through targets based on global rankings and journal lists has created a new, roundabout system of fund flow between education funding bodies and education system's beneficiaries. This leads to the boundary between what is public and what is private being blurred, to the dissolution of the academic profession as well as to the reproduction of existing hierarchies between regions and institutions (Pirie, 2009, p. 50; Szadkowski, 2015, pp. 96-101, 146)

The transformation of universities, as a result of which students become clients, while the members of the academic staff become pawns in the game, should also be considered from the perspective of such specific academic capitalism. The flow of funds between the public and private spheres, which takes place during the production and circulation of scientific work results, is a particularly blatant example of the conflict between private profits and the common good (Szadkowski, 2015, p. 172). The full state approval of the competition policy based on rankings and accepted evaluation criteria means that criticism cannot be directed only at enigmatic market forces. The rivalry launched in the academic world takes place within a fictitious market, into which flow the public funds and student tuition fees, and where the state gives the rules of global competition the status of binding law. Government interventions, which in other areas are typically aimed at reducing inequalities, in higher education are programmatically used to increase them. The long-term goal is to concentrate resources in high-performance centres and to close down the weaker ones (Readings, 2017, p. 62). Policy based on rankings reinforces the tendency to polarize higher education. The rankings differentiate not only countries, but also the students and graduates of universities (Urbanek, 2020, p. 241). The paradox is that by being stuck in a system that serves to consolidate the existing asym- 
metries and monopolies of power, knowledge and prestige, we lament the crisis of liberal democracy.

The dominant opinion is that policies and strategies that refer to economic efficiency and market mechanisms are related to neoliberal ideology. Such a view is correct only when we identify neoliberalism with its contemporary form. However, the relationship between university managerialism and neoliberalism is not obvious when we recall the assumptions of neoliberalism formulated in 1938 by the participants of the Walter Lippmann Colloquium. On the one hand, the participants of this Paris colloquium emphasised the need to oppose central planning and defended the old liberalism thesis about the right of an individual to shape their own destiny, and on the other, while calling themselves neoliberals, they emphasised that their goal was not to return to the economy of laissez-faire (Miller, 2014, p. 144). Walter Lippmann formulated a thesis that failures of liberalism were caused by the excessive focus on the freedom of an individual and on the market as well as by the insufficient involvement in the issues of economic order (Mączyńska \& Pysz, 2014, p. 223). Another founder of the neoliberal movement, Hayek (2020, p. 513), strongly emphasised the importance of academic freedom and the threat that may be posed to the development of science by those "who hold money bags". While the core of neoliberal ideology was the fear of the growth of state control over an individual, the introduction of managerialism into higher education stems from the belief that rationality and efficiency can be achieved by creating a system of central control and management of people (Miller, 2014, p. 145).

An interesting example of a metamorphosis of the interpretation of neoliberal ideas is the concept of New Public Management (NPM). This concept grew out of the liberal conviction that the private sector has an efficiency advantage and was intended to rationalise decision-making processes in the public sector. Economic doctrines (the Chicago school of economics, the Austrian school of economics, the public choice theory and new institutional economics) and managerialism are considered to be the sources of this notion (Urbanek, 2020, p. 83). Managerialism was responsible for "creating a set of doctrines for administrative reform leading to the implementation of management practices from the private sector to the public sector" (Urbanek, 2020, p. 84). While the inspiration stemming from the aforementioned economic doctrines was very complex and vague, managerialism was based on the unambiguous "belief that all aspects of organisational life can and should be managed according to rational structures, procedures and modes of accountability in the pursuit of goals defined by policymakers and senior managers" (Wallace \& Pocklington, 2002, p. 68). The critics of NPM noted that such an approach contradicted the fundamental values of both liberalism and democracy. This was most clearly addressed by Lorenz (2012, pp. 599-629), who noticed the analogies between NPM and state communism. 


\section{Democracy and short-term thinking}

The dominant mentality, exclusively valuing the ideas that can in a directly visible and linear way contribute to the economic growth or are directly useful to the government, army, religion or business, presented the universities with a choice: they would either directly contribute to the economic development or cease to exist (Bowen et al., 2014, p. 193). This opinion was based on the experiences of American universities, but it might also be applied to the changes taking place in Poland. The transition from a totalitarian to a democratic system has exposed the threats to the academic freedom in democratic societies. Paradoxically, on the one hand, democracy removes external obstacles to the free use of reason, while on the other, it creates the conditions, in which the mind is subject to assessment by the general public (Bloom, 2012, p. 322). Faced with the dangers of democracy, such as "sucking up to those in power" and focusing on short-term utility, the university must compensate for the shortcomings of democracy, resist the role of a service and provide experiences that democracy does not give an individual. The university must provide an individual with the access to competing thoughts (Bloom, 2012, p. 329).

At the same time, the product of the higher education reforms is the system of incentives directed at university employees and universities as entities financed mainly by the state. This means that both individual academics and the university bodies must adapt their strategies to the current market and political situation. In order to survive, academics must mainly focus on where to publish their works. Thinking about whether the established standards of scientific research and paradigms correspond to the needs of the changing world becomes of secondary importance. When formulating their goals or establishing statutes and pay systems, universities must respond to the current needs of economic and political markets instead of promoting a critical and long-term perspective.

The answer to the weaknesses of democracy may be, on the one hand, the revision of the utilitarian economics, while on the other, universal economic education. Such postulates were put forward by Polanyi, who examined the reasons for the susceptibility of liberalism to the attacks of communism and fascism. He considered the overestimation of the idea of the free market and the lack of boundaries, within which human affairs should be regulated by the market, an error of the utilitarian economics. Concurrently, Polanyi identified the fundamental problem of economics and the economic policy, i.e. not being able to harmoniously reconcile efficiency and distributional claims (McCants, 2016, pp. 31-32). Economic education was supposed to create hope for preventing the transformation of redistributive claims into political dictatorship as well as for avoiding the complete destruction of the benefits of the market. How up-to-date with the wave of populism are Polanyi's conditions for preventing social conflicts: understanding the principles of long-term development, universal economic education and strengthening the moral principles of peaceful development. Polanyi argued that the economy and science are characterised by 
complexity, which determines that their development and moral progress must be based on a free individual. This is consistent with the beliefs of those who defend the university as a mainstay of thinking and those who defend teaching as a process, in which critical thinking is the most important value (Heller, 2016, pp. 38-40).

\section{Attitudes of the academic staff members}

The academic staff themselves are also the factor contributing to the changes in the Polish universities. Their influence is twofold. Firstly, to a large extent, the process of the university reform results from the conviction that the university employees do not fulfil their research and teaching duties satisfactorily. Secondly, although the views of the academic staff on the functions and management of the universities are diverse, a part of the academic world either actively participates in the changes that make it more possible for the universities to be subjected to the current economic and political goals, or passively submits to them.

From the viewpoint of the assessment of the attitudes of the academics and universities, Stachowicz presented one of the most accurate interpretations of the changes in the Polish higher education. Referring to the concept of the functionalisation of pathology by Staniszkis, Stachowicz (2015, pp. 227247) states that the pathologies in the higher education system, which occur on three levels (legislative, university and individual), had positive functions. They made it easier to maintain the university budget balance, enabled the expansion and modernisation of the didactic base, helped to increase the income of the academic staff, and above all, they made higher education more accessible. Under the conditions of the functionalisation of pathology, what from one viewpoint is considered pathology, from another is a part of a rational mechanism. In this case, resisting conformism requires heroic behaviour. The strategies of the Polish universities might also be explained by the resource dependence theory based on management sciences (Anielska, 2017; Urbanek, 2019). When developing paid forms of education, the Polish universities attempted to avoid the dependence on one source as well as to create their place in a new, market environment. What happened in Poland is in line with the changes described by the researchers in the United States. Faced with a decrease in public funding, universities were forced to adopt approaches, which were characteristic for private entities. The result was a reduction in the quality of education and the deinstitutionalisation of the research function of the university (Kwiek, 2012, pp. 641-654), which consequently justified university reforms aimed at organisational and economical rationalisation as well as disciplining of the academic staff members.

However, disciplining based on financial incentives and parametric evaluation has its drawbacks. It dulls our criticism towards the system, in which we operate, and influences the choice of research topics and type of activities. It 
becomes less rational to engage in teaching activities or in reviewing and evaluating our colleague's research and publications. The division into disciplines, in spite of the ever-emerging needs of the modern world, creates "mental walls" and "rigid minds" (Konecki, 2020, p. 197).

The parametric evaluation system based on constantly changing lists of journals and publishing houses, economic conditions as well as prestige-building projects under the banner of excellence constitute a conformist incentive system, in which there is increasingly less space for combining the individual and public good. When universities have to focus on the profitability of their activities and their competitive position, they succumb to the trends set by short-term interests, losing sight of the public good. Consequently, universities themselves become a threat to the academic freedom.

\section{Conclusion}

Science and education cannot be subject to existing patterns of thinking and current economic and political forces. This is why academic freedom is not a privilege of the academic world, but one of the foundations of the successful development of a democratic society. The analysis of the importance of academic freedom, confronted with the conditions of the functioning of universities and academic staff, allows for the formulation of the following conclusions. Firstly, when Universities are driven to act like firms in competitive market places, they are following trends set by short-term economic and politic interests. They are losing sight of the public good. As a consequence, the universities themselves become a threat to academic freedom, which is one of the foundations for the successful development of a democratic society. Secondly, a political economy is an effective tool for analysing functioning of higher education operating in quasi-market conditions, imposed by the dominant market players and the state. In a crisis of liberal democracy, in order to effectively defend science and higher education against the pressure of shallow market pragmatism, we need to analyse the ideas and interests behind the modern tendency to transform market mechanism to bureaucratic structures and procedures. Understanding the forces underlying the reform of universities requires an analysis of the processes of interpenetration of economic and political processes. It means that the paradigm of political economy is gaining importance. Thirdly, in view of the requirements imposed on universities, dictated by short-term interests, the most important thing is the awareness that the necessity of state financing means that no solution will guarantee autonomy, if there is no responsibility of the academic community and self-discipline of its members. The opinion formulated at the Science and Freedom Congress, held in Hamburg in 1953 is still valid that the self-esteem and dignity of universities and individual scientists are extremely important factors allowing academic communities to become equal partners of the state to the extent that this partnership is necessary. 


\section{References}

Anielska, A. (2017). Edukacja dorosłych w ofercie szkół wyższych: strategie uczelni w świetle teorii zależności od zasobów. Edukacja, 142(3), 94-108. https://doi.org/10.24131/3724.170307.

Bloom, A. (2012). The closing of the American mind. Simon and Schuster.

Bowen, W.M., Schwartz, M., \& Camp, L. (2014). The end of academic freedom: the coming obliteration the core of purpose of the university. Information Age Publishing.

Derrida, J. (2002). Without alibi. Stanford University Press.

Graeber, D. (2016). The utopia of rules: on technology, stupidity and secret joys of bureaucracy. Melville.

Greenfeld, L. (2016). Back to 1984: the role of american universities in dismantling liberal democracy. Society, 53(4), 368-374. https://doi.org/10.1007/ sl2115-016-0030-8.

Hartl, P. (2012). Michael Polanyi on freedom of science. Synthesis Philosophica, $27(2), 307-321$.

Hayek, F. (2020). The constitution of liberty: the definitive edition. In R. Hamowy (Ed.), The collected works of F.A. Hayek, 17. Routledge. https://doi. org/10.4324/9781138400047.

Heller, M. (2016). Moralność myślenia. Copernicus Center Press.

Kahneman, D. (2012). Putapki myślenia. Media Rodzina.

Kehm, B. (2011). Być albo nie być: wpływ inicjatywy doskonałości na niemiecki system szkolnictwa wyższego. In C. Kościelniak, \& J. Makowski (Eds.), Wolność, równość, uniwersytet (pp. 229-255). Instytut Obywatelski.

Konecki, K. (2020). Uwagi na temat tego, co jest postrzegane jako ważne i nieważne w socjologii. Przegląd Socjologii Jakościowej, 16(2), 188-207. http:// dx.doi.org/10.18778/1733-8069.16.2.11.

Kwiek, M. (2012). Changing higher education policies: from the deinstitutionalization to reinstitutionalization of the research mission in Polish universities. Sciences and Public Policy, 39(5), 641-654. https://doi.org/10.1093/ scipol/scs042.

Lorenz, C.(2012). If you're so smart, why are you under surveillance: universities, neoliberalism, and new public management. Critical Inquiry, 38(3), 599-629. https://doi.org/10.1086/664553.

Mączyńska, E., \& Pysz P. (2014). Liberalizm, neoliberalizm i ordoliberalizm. Ekonomista, 2, 221-247.

McCants, A. (2016). Measuring prosperity and preserving freedom: an economic education with Michael Polanyi. Tradition \& Discovery: The Polanyi Society Periodical, 42(3), 25-34. https://doi.org/10.5840/traddisc201642320.

Miller, B. (2014). Free to manager: a neo-liberal demence of academic freedom in British higher education. Journal of Higher Education Policy and Management, 36(2), 143-154. https://doi.org/10.1080/1360080X.2013.861055. 
Morawski, R.Z.(2019). Ewolucja modelu kariery naukowej i dylematy etyczne środowiska naukowego, In J. Woźnicki (Ed), Transformacja akademickiego szkolnictwa wyższego w Polsce w okresie trzydziestolecia 1989-2019 (pp. 165-192). KRASP.

Parker, K. (2019). The growing partisan divide in views of higher education. Retrieved 18.08.2021 from https://www.pewresearch.org/social-trends/2019/08/19/ the-growing-partisan-divide-in-views-of-higher-education-2.

Pink, D.H. (2012). Drive: kompletnie nowe spojrzenie na motywację. Studio Emka.

Pirie, I. (2009). The political economy of academic publishing. Historical Materialism, 17(3), 31-60. https://doi.org/10.1163/146544609X12469428108466.

Polanyi, M. (1953). Protests and problem. Bulletin of the Atomic Scientists, 9(9), 322-340. https://doi.org/10.1080/00963402.1953.11457469.

Readings, B. (2017). Uniwersytet w ruinie. Narodowe Centrum Kultury.

Shils, E. (1954). The scientific community: thoughts after Hamburg. Bulletin of the Atomic Scientists, 10(5), 151-155. https://doi.org/10.1080/00963402 .1954.11453458.

Sławek, T. (2011). Autonomia, kształcenie, dług. In C. Kościelniak, \& J. Makowski (Eds.), Wolność, równość, uniwersytet (pp. 21-32). Instytut Obywatelski.

Stachowicz, J. (2015). Patologie organizacyjne w szkolnictwie wyższym w Polsce w latach 1990-2007. Adam Marszałek.

Szadkowski, K. (2015). Uniwersytet jako dobro wspólne: podstawy krytycznych badań nad szkolnictwem wyższym. PWN.

Urbanek, P. (2019). Teorie ładu akademickiego. Gospodarka Narodowa, 300(4), 5-30. https://doi.org/10.33119/GN/113062.

Urbanek, P. (2020). Ead akademicki w uniwersytecie korporacyjnym: teorie, instytucje, efektywność. Uniwersytet Łódzki.

van Noorden, R. (2013). Open access: the true cost of science publishing. Nature, 495, 426-429. https://doi.org/10.1038/495426a.

Wallace, M., \& Pocklington, K. (2002). Managing complex educational change: large-scale reorganization of schools. Routledge.

White, S., \& Creaser, C. (2007). Trends in scholarly journal prices 2000-2006. Retrieved 18.08.2021 from https://www.lboro.ac.uk/microsites/infosci/ lisu/downloads/op37.pdf.

\section{Acknowledgements}

Author contributions: author has given an approval to the final version of the article.

Funding: this research was fully funded by the University of Lodz.

Note: the results of this study were presented at 4th Scientific Conference: Institutions in Theory and Practice (March 25-26, 2021, Wrocław, Poland). 
